\title{
CUBAGUA, OR THE SEARCH FOR VENEZUELAN NATIONAL IDENTITY
}

Emperatriz Arreaza-Camero

In an interview with Richard Kearney, Paul Ricoeur pointed out that "the implications of narration as a retelling of history are considerable. For history is not only the story (historie) of triumphant kings and heroes, of the powerful; it is also the story of the powerless and dispossessed. The history of the vanquished dead crying out for justice demands to be told" (Kearney 17).

I think this statement, broadly construed, produces the possibility of exploring new ways to understand the history of the last 500 years in the Americas. In 1992, the world commemorated the "discovery" of America by Columbus, and the violent encounter between two different cultures-European and Native people-that ensued after 1492. From that moment until the present, there have been at least two contradictory interpretations of this historical fact: on one hand, there is a perspective that presents the Spanish conquest as a positive process of culturalization and christianization brought by Europe to the savage New World, while on the other hand, there is the critical position that explains that process as a colonial and imperial act of genocide and cultural destruction by European civilization against the ancient Native cultures of the Americas.

One could interpret this historical fact as the encounter between "hot societies" and "cold societies" (following Levi-Strauss's concepts as used by Ricoeur), in which hot societies "whose symbolic systems change and evolve over time, carrying within themselves different layers of interpretation and reinterpretation" imposed their cultural criteria and power onto cold societies which, according to Levi-Strauss, were "resistant to historical change" (Kearney 25). This 
interpretation of history would support the victors' point of view. But, as Ricoeur said, "cultures create themselves by telling stories of their own past. The danger is of course that this reaffirmation can be perverted, usually by monopolistic elites, into a mystificatory discourse which serves to uncritically vindicate or glorify the established political powers" (Kearney 29).

For many years, the cultural history of the Americas has been explained from the point of view of the powerful "hot societies." Theirs has been the "official story" presented in canonical discourses like textbooks, literature and also traditional cinema. From John Wayne's westerns to the most recent liberal movies on indigenous populations, the Native people have been portrayed by Hollywood either as the evil force who "massacred" the white pioneers, or as the weak and naïve savage who must be converted, rescued and saved by the white hero. Within the last decade, it seems that the American film industry has become interested in reviewing the history of the relationship between Europeans and Native people of both Americas.

For example, in 1986, The Mission's main point was to portray the struggle for power and possession of Native territories among the Spanish and Portuguese empires, the institutional Catholic Church and the Jesuit settlements in the eighteenth century in South America. In this movie, the Native people were presented as passive followers of the "good European missionaries" who fought for them against the "bad European soldiers," but the Natives did not decide by themselves their own destiny.

Although recent North American films give Native people the opportunity to show their own individuality and self-determination, there is always a white savior who mediates between the Natives and the white authority or society; such is the case of Dances with Wolves (U.S. 1990), At Play in the Fields of the Lord (U.S. 1991), Thunderheart (U.S. 1991), Black Robe (Canada 1991), and The Last of the Mohicans (U.S. 1992). Even though each movie deals with different tribes and historical periods in both North and South America, their common point is the futility of the Native people's voice and protest; at the end it is always the white invader who will decide for them and take their land. As Ward Churchill points out:

indigenous peoples have been reduced in terms of cultural identity within the popular consciousness-through a combination of movie treatments, television programming and distortive literature-to a point where the general public perceives them as extinct for all practical intents and purposes. Given that they no longer exist, that which was theirs-land, resources, heritagecan now be said, without pangs of guilt, to belong to those who displaced and ultimately supplanted them. (16) 
A particular ideological device used by the mainstream film industry is the portrayal of Native peoples from the Americas as "creatures of another time," defined by eurocentric values and homogenized by the generic word "Indians" which does not take into account the different names, histories and traditions of all the tribes, clans, and indigenous groups dispersed through North, Central and South America.

Because of the oppressive implications of these portrayals, it is important to consider a more critical perspective-that of the powerless and oppressed-that has been used to propose a different interpretation of history in transgressive discourses such as Latin American literature and cinema. This critical point of view can bring about the possibility of a "positive utopian discourse," which, according to Ricoeur, permits the "imaginaire of rupture" that would break the dominant discourse around the history of Spanish conquest and colonization in the Americas (Kearney 29).

In that context, it is important to look at "indigenist cinema," as Octavio Gettino calls the documentaries and feature films of/on indigenous peoples produced by Latin American filmakers in recent decades, some of which were presented in 1985 at the first Latin American Festival of the Cinema of Indigenous Peoples in Mexico. For Gettino, "indigenist cinema" is:

a cinema that takes part: that is to say, it knows beforehand the most important part of a [specific] situation, and focuses on testimony, denunciation, or the dissemination of this [situation]. As a consequence, there is a prioritizing of certain themes among many others that are possible, taking into account the mobilizing effect that each of them can have in specific spaces and circumstances. $(59)^{1}$

"Indigenist cinema" is an important genre of the New Latin American Cinema, and follows the theoretical and political approach of the "Third Cinema" proposed by Solanas and Gettino in 1969 as a way of filmaking with concrete political commitments toward the struggle for liberation. It arose in many Latin American countries in the 1960s, following the hope of radical social change provoked by the experience of the Cuban revolution in 1959. Venezuela has played an important part in the development of this New Latin American Cinema movement since 1968, when the first Festival of Latin American Filmakers was organized by the Department of Cinema of the University of Los Andes (Mérida).

Particularly significant at that time were the Venezuelan filmakers' denunciations of the continuous invasion of the Native peoples' lands in the Venezuelan Amazon in the name of progress and modernization. A governmental project, "The Conquest of the South" 
(La Conquista del Sur), had opened the south of Venezuela to the transnational companies' interests and profits. The Department of Cinema at the University of Los Andes financially supported Donald Myerston's Atabapo (1968), on the tribes of this region on the southern border with Colombia; Michael New and Roberto Siso's Warao (1973), on the Warao tribes of the Orinoco delta; and Armando Arce's animated films Karina (1977), Wanadi (1981) and El sueño de los hombres (1986), which relate the myths of creation and cultural survival of the Karina (Caribe) and Ye'kuana (Maquiritare) tribes in the Amazon.

Also, the University of Zulia produced Rafael Araujo's Zonas de Refugio (1974) on the Bari tribe in the country's northwest forest; José Gutiérrez's Cerca de la tierra de los Guajiros (1976) and Luis Correa's Sumain wayu, tierra Guajira (1975) on the Wayu tribes (from the Arawac family) along the north Colombian-Venezuelan border. The National Open University produced Alain Houel's Los Indios: pasado, presente y futuro (1980), on the Piaroa and Ye'kuana tribes. The Central University of Venezuela in Caracas produced Carlos Martín's Cuivas (1971), on a tribe from the south side of the Orinoco River, and Alberto Moret's El papel de la mujer en la sociedad Guajira (1981) on the matriarchal social organization of the Wayu tribes. The Interamerican Institute of Folklore and Ethnomusicology produced Ruben Méndez's Waki paevi wahi (1977) and Oko Winikina arao (1979) on Guajibo and Warao musical traditions, respectively, and the Venezuelan Institute of Scientific Research (IVIC) produced Matilde Suarez's Los Waraos del Delta del Orinoco (1968).

Other ethnographic documentaries were made by independent filmakers with the financial support of the Ministry of Education, the Guayana Corporation (in charge of the project "The Conquest of the South"), the Indigenist Commission of the Ministry of Internal Affairs, or the Catholic Church. Examples of this production are Luis Cocco's Los Guaicas (1965) and Daniel Oropeza's Paraíso Amazónico (1970) about the Yanomami tribe at the Brazilian-Venezuelan border; Henri Corradi's Los Indios Panare (1973); Oscar Garaycochea's Guayana, reto y futuro en Venezuela (1977), with a developmentalist approach; and Carlos Oteyza's Santa Elena de Uairen (1979) on the Pemon tribe. Most of these films were produced in $16 \mathrm{~mm}$ color, were 20-30 minutes long, and were produced for educational, promotional or scientific rather than commercial purposes. ${ }^{2}$

Very important in the political current of Venezuelan indigenist cinema were the documentaries directed by the independent filmmaker Carlos Azpurua: Yo Hablo a Caracas (1978), in which a Ye'kuana shaman denounced the invasion of their land by North American missionaries from the "New Tribes" group (Nuevas Tribus) 
and the consequent destruction of their Native culture ${ }^{3}$; Bongo maquiritare (1978); Cano Manamo (1979), in which the Warao tribe denounced the ecological destruction of their original environment in the eastern Orinoco delta by transnational companies; and Amazonas, el negocio de este mundo (1986), in which Azpurua denounces the transnational businesses that search for strategic minerals in the heart of the Amazon with the approval of the Venezuelan government (Cronología del cine en Venezuela). Azpurua's research prior to each film, and his subsequent film distribution and exhibition, are always the object of governmental alarm and persecution because all of his films are explicit condemnations of the current "foreign invasion" by transnational companies in the search for natural resources (oil, steel, uranium and other strategic minerals) on the Native tribes' lands without any concern for the environmental destruction that ensues, in many cases, with complicity from the Venezuelan government and national private businesses.

A different approach to the indigenous aspect of Venezuelan culture has been presented by the experimental filmaker Diego Rízquez in his historical trilogy. The first film of the trilogy, Bolivar, sinfonia tropikal (1980), represented in a theatrical performance the life from birth to death of the Liberator Simon Bolívar, while the second, Orinoko, Nuevo Mundo (1986), combined an ethnographic documentary of the Yanomami tribes of the Orinoco river with a baroque mise en scene showing the experiences and visions of foreign visitors (Spanish conquerors and missionaries, English pirates, and German scientists) to the Venezuelan Amazon in the first three centuries after Columbus's arrival in the "Land of Grace." Finally, his Amerika, terra incognita (1988), began with the departure from the Venezuelan coast of Columbus's boat in 1499, and his arrival at the Spanish Court in the company of parrots, tigers, tropical fruits and plants, and a Native prince who was incarcerated and confined to an imaginary island across from the royal palace. In Rizquez's Amerika, the Shakespearean tragedy of Prospero-Miranda-Ariel-Caliban is reinvented, making possible the birth of the first mestizo bastard in the Spanish palace, and not in the remote "Terra Incognita."

\section{Cubagua: A Review of Venezuelan History}

The 1987 film Cubagua (directed by Michael New and based on Enrique Bernando Nuñez's novel of the same title) presents a reinterpretation of Venezuelan national history in which the process of conquest, colonization and independence is not yet finished but is instead an ongoing and important element in the formation of Venezuelan "national identity." Traditionally, the history of Latin American countries has been presented as a set of distinct stages: conquest 
(from the "discovery of America" until the first foundations of cities by the Spaniards), colonization (from the sixteenth to the beginning of the nineteenth centuries), wars of independence (the first three decades of the nineteenth century), and finally, the constitution of the Latin American republics (from the mid-nineteenth century until today), with the foundation of the "Nation-State."

In this view, the wars of independence are seen only as an economic and political conflict of interests between the "Creoles" and the metropolitan Spaniards, and not as a continual struggle for "national liberation" by subaltern groups. As Benedict Anderson argues:

the two factors most commonly adduced in explanation [for the Spanish-American empire's fragmentation] are the tightening of Madrid's control and the spread of the liberalizing ideas of the Enlightenment in the latter half of the eighteenth century. (21)

In that context, it seems that the Creole upper classes of the nineteenth century used metropolitan instability for their own benefit in restructuring political and economic control in the Spanish colonies. In doing so, they did not change substantially the geographical space occupied by each South American territory before the war of independence, nor did they develop a national consciousness or sense of a Nation-State independent from the Spanish empire.

From that period on, the assumption of having a particular nationality changed people from "Creoles" to "nationals." Yet there were profound class and racial inequalities in the new republics as a legacy of the colonial period. The Creole ruling classes were insensitive to social injustice and the unequal distribution of land, wealth and opportunities for all of the social groups (Natives, Blacks, and Mestizos) who had fought for radical and structural change during the wars of independence.

In contrast to the theory of developmental stages, there is another position which explains the formation of the Latin American countries into what German Carrera calls an "implanted society," in which the initial occupation of the territory by the conquerors established a network of interaction with the natural environment, and between both cultures (Native and Spanish) in an unequal and conflictive encounter that persists today. This mode of "implantation" has determined the social formation of the Latin American countries from the very beginning. In the case of Venezuela, "the first Spanish settlement [after 1498], the oil exploitation and the massive immigration of the 1950s would be steps in the same process. . . . From this point of view, there is no break in the historic process within the Venezuelan social formation" (Carrera 25). 
Also, each phase of settlement was determined by the exploitation of natural resources and their importance for the international market in each historical period. The extraction of pearls and gold by the Spanish conquistadors in 1500 , the production of coffee and cocoa in the 1600s and 1700s, and oil exploitation from the mid-1900s on by transnational oil companies are the "key points" to a comprehension of Venezuelan national history.

Carrera argues that the traditional way of understanding the history of Latin America through different and unrelated periods has pervaded the "national consciousness." During the nineteenth century, Venezuelans rejected their colonial past, and separated themselves from the colonial social formation, thus forming something totally different. The ideological veneration of the "national heroes" who achieved independence makes the ideal of a bright national future easy to imagine, but not with "all" people working as a "nation" toward this goal. A key point in Carrera's argument is the evident ignorance of Venezuelans not only of their national history (Venezuela is considered by many critical historians, like Carrera himself, to be "a country without memory"), but also of their national geography. ${ }^{4}$ Foreign visitors have been the people who have "discovered," in each period, the wealth of the Venezuelan land and its natural resources.

Christopher Columbus landed in Venezuela in 1498 on his third voyage; he called it "Land of Grace" or Tierra de Gracia.5 In 1499, Alonso de Ojeda, Juan de la Cosa and Amerigo Vespucci traveled along the Venezuelan coast from Paria to the Guajira, where Vespucci gave Venezuela its name, in remembrance of his "Little Venice." In 1505 the first Spanish settlement in South America was established on the tiny island of Cubagua, northeast of Venezuela, thanks to its wealth of pearls, and the lucrative business of indigenous slavery established by the first Spanish colonizers (Jiménez 160). Then, in the eighteenth century, the German Baron Alexander Von Humboldt described in his travel memoirs the immense and rich variety of Venezuelan natural resources and its cultural and social life. Most recently, in the 1980s, NASA satellites "discovered" for the transnational companies the hidden deposits of heavy oil and other strategic minerals in the Orinoco River basin and the Venezuelan Amazon that would initiate a new process of exploration. In every case, the colonialist manipulation has favored the appropriation of Venezuelan natural resources, a cheap labor force, and wealth by foreign capitalists with the complicitous approval of the national ruling classes.

In that sense, Carrera's argument about Venezuelan history echoes that presented by Immanuel Wallerstein when he defined his concept of "world-economy system" as "one in which there is an extensive division of labor [that] is not merely functional-that is, 
occupational-but geographical" (32). Venezuela's economic dependence on a world economic system has also determined a social structure in which the national ruling class establishes and justifies its economic and political power supported by the ideology of the socalled "National Project," especially from the second half of the nineteenth century to the present.

The first Venezuelan National Project was formulated after the Independence wars (1810-1824) with the purpose of unifying the territory under the newly-founded Republic of Venezuela and formulating a "national identity" in the organization of the Nation-State. Guzman's presidency (1870-1890) saw the creation of the economic infrastructure, which helped the formation of a national market and invited foreign investments, inserting Venezuela definitively into the world capitalist system. Along with the economic was the ideological aspect of the National Project, enacted in the formulation of a new Constitution which tried to make a more egalitarian society through the creation of obligatory elementary education for all citizens and promoted national unification around the cult of the hero Bolívar. These are some factors in the creation of Venezuelan national identity during the consolidation of the Nation-State that persist, with some variations, until today.

The national project formulated by Guzman was a failure at that time, because the mono-cultural production of the country (mainly coffee and cocoa) did not satisfy the needs of the world capitalist system in the late $1800 \mathrm{~s}$. It was only with the oil exploration in the 1930s that Venezuela began its full and final arrival into the world capitalist system. As Carrera points out:

the complete articulation of the Venezuelan implanted society
into the world-capitalist system appears by the effect of an
external and dynamic factor, oil, that stimulates the renewal of
theprocess of implantation interrupted at the end of the eigh-
teenth century. (136)

Oil exploration began in the mid-1930s during the last years of Juan Vicente Gómez's dictatorship (1908-35). In the 1950s (under the Pérez Jiménez regime of 1950-58, the last Venezuelan dictatorship) massive oil exploitation by American oil companies on the Venezuelan west and east coasts allowed for: (1) the creation of new cities, (2) more rural-urban migration and the consequent social marginality of the lower classes, (3) the possibility of an easier social mobility for the middle classes, and (4) a pervasive process of "transculturation" for the ruling classes, which looked after their own economic, social and political interests to the detriment of the "national popular culture." The "culture of oil" caused deep changes in the economic, 
political, social and cultural life of the Venezuelan population. The effects of economic dependence after the oil exploitation had a big impact on national cultural identity: to the cultural mix of Spanish, Native and African elements was added the "American way of life" (Chacón 177).

As Wallerstein argues:

in a world-economy the political structure tends to link culture with spatial location. The reason is that in a world-economy the first point of political pressure available to groups is the local (national) state structure. Cultural homogenization tends to serve the interests of key groups and the pressures build up to create cultural-national identities. (349)

In the Venezuelan case, the national ruling classes had been heavily involved with foreign corporations in order to be economically powerful, and this connection had prevented a local nationalistic approach to the culture developed by the ruling class. Venezuela, from the mid1950s (and especially in the 1970s with the rise in oil prices), had imitated the consumerist "American way of life" more than any other Latin American country. Venezuela in that contradictory decade conveyed "the schizophrenia of a [country] that is neither Latin nor completely Americanized but rather a hybrid monster which combines the most distressing aspects of both: extreme contrast of wealth and poverty" (Burton 67).

Carrera's critical interpretation of national history as a continuing process of neo-colonial appropriation of Venezuelan natural resources by foreign invaders with the approval of the national ruling classes creates the basis for the struggle not only for the recovery of "national identity," but also for the "redefinition of popular memory" in a country that has been losing its collective memory and historical sense in each economic "invasion."

The Venezuelan writer and historian Enrique Bernardo Nuñez wrote the novel Cubagua in 1929-30 and published it in 1931, at the very time of the rise of "the culture of oil," during Gomez's dictatorship. Nuñez's main passion was historical research and the reinterpretation of national history, since for him, "a nation without memory of the past suffers a kind of death" (La historia 23). Nuñez's position supports Carrera's definition of Venezuela as a "implanted culture" conditioned by different kinds of invasions. Nuñez introduced the internal contradiction of history itself, when he argued that

the history written by the dominant races will always be different from the interpretation given by the vanquished or oppressed peoples. ... [T]he Conquest does not end in the seventeenth century, nor does the colonial period properly culminate in inde- 
pendence. All of this flourishes into a permanent present. There are three stages that are prolonged until our own time. It could be said that allour past is present. (La historia) ${ }^{6}$

\section{Historical Antecedents of Cubagua, the Novel}

Nuñez began his search for the brief but tragic history of Cubagua in 1924, when he moved as a journalist to the island of Margarita. At that time he researched Nueva Cadíz, Cubagua in the archives of a Franciscan convent. The island of Cubagua got its notoriety in the early sixteenth century from its wealth of pearls and the lucrative slave trade that the Spaniards ran there from 1505 to 1540 , but the island was abandoned after the exhaustion of the pearl banks and after many Caribe attacks conducted in retaliation for Spanish cruelty.

According to the Indian Chronicles, ${ }^{7}$ the direct exploitation of pearls on Cubagua was so productive that in 1512, King Charles I gave the Spanish "explorers" not only authorization for the extraction of pearls, but also the "perpetual concession" of the indigenous people "rescued" in the north of Venezuela and surrounding islands (Jamaica and the Minor Antilles). Officially, the Natives would be "rescued" via their christianization, but the reason behind the "rescue" was to use them as expert divers in the extraction of pearls. The indigenous slave trade in Cubagua was an "indirect" but very profitable business on the island (Jiménez 162).

In 1520, Antonio Flores, one of the cruelest mayors (alcaldes) in this settlement, killed a native chief from Cumana, in the south of Cubagua, as well as an indigenous woman and many other indigenous people who would not give him the extracted pearls. The men were hanged, and the woman was burned on a cross (Jiménez 164). In response, the Caribbean tribes of the northern coast of Venezuela attacked and killed more than forty Spaniards. After this event, the Spaniards took revenge, but the Natives poisoned the water of the island of Margarita, affecting the life of the people living on Cubagua. As Morella Jiménez points out:

The hostility of the indigenous people was not only against the "rescuers" but also against all the Spaniards. This is evidence of the capacity for organization and unity that all the indigenous communities had when the situation [of aggression] required their action. $(165)^{8}$

This perspective contrasts with that of traditional literature and cinema, which portrays the Natives as a cowardly and passive population that gave itself to the Spanish conquistadores without fighting back. The current revisionist history of the Americas, as it is presented in 
recent Latin American literature and cinema, illustrates with new evidence the Native Caribes' struggles on Venezuela's northern coast.

However, the extraction of pearls and the enslavement of the indigenous population continued for the next twenty years with the permission of the Real Audiencia de Santo Domingo (which ruled the province of Venezuela at that time). An interesting anecdote illustrates the power and independence of the Cubagüenses in their successful enterprise. In January 1528, the King of Spain gave Luis de Lampugnano, a nobleman from Milano, a concession for six years for the monopoly of the dredging of pearls on Cubagua. But, as the procurator of Cubagua protested that decision, the King revoked the concession to Lampugnano nine months later (Anales 49-50). In 1538 the pearl banks were totally exhausted, and in 1540 Cubagua was completely abandoned after a strong tropical storm. Only the ruins of the Franciscan convent survived.

Based on these historical events, Nuñez presented his critical approach toward the comprehension of Venezuelan national history in his novel about the island. Illustrating the continuity of past and present, Cubagua takes place in two different time periods. In the narrative time (1925), the main character Ramon Leiziaga, a government employee, travels to Margarita in order to supervise Stakelun's magnesium mines. Searching through some old documents left in a Franciscan convent, Leiziaga identifies himself with Lampugnano, the main character of the historical time (1500s). In his passage through different eras, Leiziaga finds that Fray Dionisio, the priest who protected the Natives in 1500, is in 1925 his own guide through Cubagua's caves. And Nila Calice, the indigenous woman who was burned on a cross by the Spaniards in 1500, is in 1925 an indigenous chief's daughter, a well-educated woman who reprimands Leiziaga for his ambivalent position. In both time periods, the novel portrays the confrontation between the invader with his technology, and the popular forms of active or passive resistance utilized by subaltern groups.

In contrast to the pragmatic position taken by the Venezuelan technicians and foreign businessmen who only want to enrich themselves with the land's wealth, the lessons of the past are recovered through Fray Dionisio's voice and Nila Calice's actions, which both constantly remind Leiziaga of the continuing process of conquest and colonization in a "country without memory," and of his responsibility for the defense of national resources, land and culture as the only way to survive.

Nuñez, in the 1930s, was ahead of his own generation. His narrative was a political and ideological tool for the recuperation and reinterpretation of national history (Oropeza 92). Moreover, in Cubagua, the idea of the "mestiza," as a woman of mixed blood, was 
crystallized not only as a symbol of Venezuelan national identity, but also as an active seeker of complete national liberation. Before Nunez, there were other Venezuelan writers who used the allegory of the "mestiza" as a positive symbol of the patria (native country), which had to be saved from the foreign intruders or the unfaithful Venezuelans.

During Gomez's dictatorship, the solution to Venezuela's socioeconomic crisis that was presented by the traditional intellectuals was to overcome the "barbarism" of the country's backwardness with the "civilization" coming from the rising capitalist societies that wanted to invest in the country. Their solution was to open doors to the foreign investors who would bring capital and technology and also "whiten" the mixed population (Wright 107).

Another group of intellectuals, antagonists of Gomez's regime, used the allegory of the "mestiza" as a symbol of a national identity that had to be preserved as the only way to survive both the intervention of the new invaders and the irrationality of bad governments. For example, Francisco Lazo Marti's poem "Patria, La Mestiza" (1909) and Jose Rafael Pocaterra's story "Patria, La Mestiza" (1922) represented the native country as a woman who awaits the return of the prodigal man, who has left either for the North (as in Lazo's poem) or for the irrational war (as in Pocaterra's story), in order to begin a new life in his own land. In both scenarios, the woman assumed a more passive but wiser role than the man who returned to her. Also, Romulo Gallegos' novel La trepadora (1925) presented the idea of the native culture through the character of the "mestiza" Victoria, who is "la trepadora," the woman who overcomes the racial prejudices of her social environment and improves her own circumstances. 9 But it is in Nuñez's Cubagua that the allegory of the "mestiza" as symbol of the native culture is assumed by an active woman who does not wait, but goes forward. Nila Calice has traveled as much as Ramon Leiziaga, and both have earned degrees from foreign universities. Both returned from the North to the native land, but their attitudes are very different: Leiziaga wants to be involved in large-scale projects, to transfer the concession to a foreign company, and with this money, to retire and move to Europe. In contrast, Nila dazzled her professors (in Europe and the U.S.) with

her pearls ... her stories. . . The white man would begin to weave around her a heavy net of artifices. Sometimes, they thought she was naïve and easy, but suddenly she would appear as the daughter of Rimarima and owner of the lands that did not give up her secret. . . The man rarely understands this. In the woman it is possible to find everything, life, energy. The man rushes to her with a blind impulse and does not know that he is only her instrument. $(61-2)^{10}$ 
More than fifty-five years later, Cubagua was adapted to the screen by Michael New.11 Like Nuñez's novel, the film tells the (hi)story of a "country without memory": the continual conflicts that arise from the process of conquest and colonization by foreign invaders and a corrupt national government, and the cultural resistance struggles of the Native people. The film follows the narrative structure of the novel, but adds another historical moment: the transnational exploitation of strategic minerals in the 1980s.

As part of the Venezuelan cinema of the late 1980s, Cubagua can be taken as representative of the "remembrance phase" of Third Cinema in which there is "the indigenization and control of talents, production, exhibition and distribution" (Gabriel). It also represents a "return to pristine cultural sources," which preserve national culture and history by redefining the popular-national in contrast to the transnational. This idea of preserving national culture as popular resistance against the hegemonic power (of transnational capitalism or the national bourgeoisie) "emphasizes the thick texture of hegemony/subaltern relations, the interlacing of resistance and submission, opposition and complicity" (Martín-Barbero 465).

In this context, Cubagua reinterprets the history of a "nation that has been losing its memory," and also the conflict between the "traditional intellectuals" as representatives of the national bourgeoisie in their alliance with the transnational hegemonic power, and the "organic intellectuals" (critical historians, writers, and filmakers) who are in dialogue with the Native people in their search for "national identity."

Martín-Barbero points to the importance of national cinema which

connects with the masses' hunger to make themselves socially visible . . . [and] gives a human face to the people, and by allowing them to see themselves, it encourages an identity vital for the urban masses, diminishing the impact of culture shock and for the first time letting them perceive the country according to "its" image. (463)

The importance of this national cinema and its political vigor can be understood as linked to "the idea of active resistance" (Mattelart and Mattelart 165). In that sense, the reinterpretation of national history by a committed literature and cinema is not merely an intellectual and nostalgic remembrance of the glorious and autonomous past; it is a way to raise the national consciousness in order to develop an integral process of economic, political and cultural liberation. 
Prior to this film, Michael New co-directed with Roberto Siso (Cubagua's editor) the documentary Warao, which relates the history, life, and traditions of a Native tribe that still lives in the Orinoco River delta. In 1974, New directed Rosa de los vientos, based on Edmundio Quintero's novel of the same name'2, and in 1978 he made $35 \mathrm{~mm}$, on the Venezuelan guerrilla movement of the 1960s. Throughout his career, Michael New's filmography has been a reflection on the Venezuelan past and its influence on the current national situation.

In Cubagua, his first feature film, Michael New plays with time "in a search through history that relates past with present." As New points out:

it is indispensable that the people learn about their history, and in Venezuela one feels the lack of history; the history is not up to date, it is not present, it is like the people want to forget the past, and go only to the hypothetical "future progress," that is false. I believe if we do not look at the past, who we are, where we came from, we never will know where we will go. In that sense, Cubagua is a very important project. (qtd. in Calzadilla 79)

The point of encounter and contact in both novel and film is the notion of "transhistoricity," as "a simultaneous field in which all times interpenetrate, intertwine, and conform to the same current time" (qtd. in Calzadilla 85). This concept of transhistoricity follows closely Carrera's characterization of Venezuela as an "implanted society," in which the process of conquest, colonization and independence are continuous elements from the past to the dependent and neocolonial present. Cubagua seeks to recover national culture by raising critical awareness of national history in order to achieve an authentic national identity characterized by economic, political and cultural self-determination.

During the 1980s, when the film was produced, there was an important discussion in the Venezuelan Congress regarding new investments by transnational companies in the Amazon and their extraction of strategic minerals useful for U.S. nuclear and space research. Exposés of these investments were made by Venezuelan free lance journalists and filmmakers at the risk of their own lives.

Cubagua's main character lives three different lives in three different time periods: in 1520, as Lampugnano, the Italian inventor assisting the Spaniards in the extraction of pearls; in 1930, as the engineer Leizaga helping the North American oil companies in the exploration of oil on Margarita, an island close to Cubagua; and in 1980, as Leiziaga, another engineer helping the transnational companies in the extraction of strategic minerals in the Venezuelan Amazon. At the end, the character experiences a change in consciousness, an 
awakening, as he ceases to be an instrument of the exploiter and becomes an instrument for the recovery of national self-determination with the help and support of Nila Arias.

The film is organized into twenty-five segments, in which the three different historical periods are interconnected through Fray Dionisio's narration and/or the journalist Nila Arias's reprimands directed at the Leiziaga of 1980 . The first segment begins in 1980 , when Leiziaga (Heberto Gabaldon) is leaving Caracas. His boss Carvallo (Reinaldo Mirravalles) is wishing him good luck in his trip to the Venezuelan Amazon, where he will search for minerals for Carvallo's transnational enterprise called "Proyecto Progreso" (Project Progress). While Leiziaga is flying over the forest, the voice of Nila (Sonia Lopez) reminds him: "they are using you, because they need your technical knowledge."

In the second segment, Leiziaga (now in 1930) is landing on the island of Margarita, where Stakelum (Mirravalles) picks him up, and introduces him to the island's authorities, among them Dr. Figueiras (Hector Myerston). Figueiras asserts that the government's involvement in Mr.Stakelum's mine business "will be good for everybody, and everybody will take part in the lucrative profit." After this encounter, Leiziaga decides to go to Cubagua, where he hopes to find petroleum, just as four centuries ago conquistadors sought pearls. He arrives at night, and is met by Fray Dionisio, Paraguachi's priest. Fray Dionisio (Julio Mota, who was the narrator in Wanadi) introduces Leiziaga to his protegée Nila (López), and to Cubagua's old maps. Fr. Dionisio begins to narrate for Leiziaga the (hi)story/legend of the Count of Lampugnano (Gabaldon).

In the third segment, set in 1500 , the alcalde Antonio Flores (Myerston) is talking to Lampugnano about their mutual interest in Cubagua's business: pearl extraction and enslavement of indigenous peoples. At the end of this segment, Fr. Dionisio narrates how the Native woman (also played by López), burned by the Spaniards in revenge for the Caribes' attack on Cubagua, took over Lampugnano's mind forever.

Throughout the film, Fr. Dionisio always points out to Leiziaga the fleeting nature of history, and its similarity to the current situation. Fr. Dionisio, to Leiziaga's surprise, insists: "you will have time to understand it all." In Cubagua, Fr. Dionisio's narration presents, in a sort of historical montage, the three different enterprises in which Lampugnano/Leiziaga is involved, and his responsibility for the exploitation of the land's wealth and indigenous population. The "transhistoricity" of the film is played out through the successive flashbacks and flash-forwards where, 
all the times work and interact in the same field of simultaneity in which each individual represents a transhistoric lineage, eternally present. Leiziaga's monoexpressivity in the film is justified by the fact that he is an immobile time traveler, or better, that through him the "transhistorical time" is revealed, which produces everything in its eternal simultaneous return, in which Leiziaga is the "transhistoricized" automaton, as all the other characters, insidiously repeated in different costumes, enslaving Natives or bribing journalists. (Calzadilla 86-7) ${ }^{13}$

The use of music is also significant in the film. When Fray Dionisio is narrating in voice-over (in the scene of the supper that brings the alcalde Antonio Flores and the royal emissary Diego de Ordaz together) the music is baroque, performed by Spanish musical instruments. It is reminiscent of the music used by Tomás Gutierrez Alea in The Last Supper (Cuba 1976) for the scene of the supper served by the white master to the African slaves. But when Leiziaga and Fray Dionisio descend to the Natives' caves, the music is the "Maquiritare areito," used previously by Armando Arce in Wanadi, which tells the creation myth of the Caribbean Ye'kuana tribe. It is important to point out that in Cubagua, New is aware of the meaning of the traditional rhythms, musical instruments, and dances in Native cultures. The contrast between Fray Dionisio's baroque musical background and the indigenous music of Karina and Ye'kuana communities is pointed out in the "transhistorical" scenes.

The camera angle is another cinematic device used in Cubagua to position the characters politically. For example, when Lampugnano is talking with Antonio Flores in the scenes from the 1500s, with Stakelum in the 1930s, or with Figueiras in the 1980s, the straight-on angle assumes an equal relationship-signifying agreement or complicity in their business. By contrast, the frame relation between Nila and Lampugnano/Leiziaga reveals a different perspective. For example, when Nila is burned by the Spaniards after the Caribes' attack, a low-angle shot positions her executioners, including the passive Lampugnano and the public, at her feet looking up at her. She seems to be above the others, transcending her own suffering toward an unknown future. Through framing techniques, Nila is always privileged by the film as the symbol of the "recovery of the past." Leiziaga, by contrast, is often presented from a high angle. For example, in one of the last scenes, when he discovers his role as instrument of the exploiter after his visit to the Natives' caves, he is framed in a high angle which positions the spectator looking down on him, until he seems like the smallest ant in the immensity of the landscape. This contrast emphasizes each character's approach to the land and their level of toma de conciencia or responsibility in the struggle for national self-determination. 
Cubagua's last eight minutes synthesize the three temporal spaces, and the main characters' positions, showing: 1) Lampugnano as a passive and cowardly spectator of Nila's torture in the Spanish fire. Nila and Lampugnano exchange gazes of mutual recognition as Nila, valiant, suffers the torture in silence, while Lampugnano, also silent, is only an observer, an accomplice of the Spanish abuse, uncommitted. 2) The engineer Leiziaga, as a passive and confused observer of the Caribbean dance, receiving the Spanish armor with fear due to his status as a mestizo who cannot define himself as either completely Native or Spanish.14 3) The engineer Leiziaga, alone in the immensity of the land, becoming an active participant in its final liberation. For him, it seems that the rescue of the documents which prove transnational operation in Venezuelan territory will allow him a new opportunity for utopian national liberation and a "return to the primary roots" exemplified by the Native woman who comes out of the cave into the light, toward an unknown future of open possibilities.

The film presents the future as the rediscovery of the past and shows an awareness of popular struggle in each epoch. In the film's last scene, Nila, the Indian woman tortured in 1520 , awakes in 1980 alive and free: she embodies the utopian possibility of liberation for the indigenous and mestizo people in Latin America after 500 years of popular resistance. The final images of Nila are, successively: as a victim tortured by the Spanish conquerors in 1500; as the Tamanaco chief Rimarima's daughter and Leiziaga's inner voice in the 1930s; and finally, as the intrepid and courageous journalist who denounces transnational capital's robbery of strategic minerals in the Venezuela of the 1980s. Nila is a metaphor for the recovered and "rediscovered" land: Cubagua, Venezuela, Latin America.

In Cubagua, Nila, the Venezuelan mestiza, "has gone from being the sacrificial goat to becoming the officiating priestess at the crossroads" (Anzaldúa). But unlike Anzaldúa's concept of the mestiza, Nila never had to be the "translator" or the "traitor," La Malinche, in order to take her place in history or myth.15 In each historical period represented in the film, Nila assumes an active role in the defense of her own land and people. Nila, like Doña Marina, is an indigenous chief's daughter. But unlike Doña Marina, Nila is a Native descendant of the Tamanacos, a warrior Caribe tribe, that five centuries after the Spanish conquest still fights and resists against new invaders. Thus, even though historically she has been burned on a cross, she is resurrected cinematically as a symbol of Venezuelan national liberation.

As she leaves the cave at the end of the film and walks into a bright light, there are no marks of torture in her body. This is the final allegory for the "unconquerable" desire for freedom of indigenous cultures. ${ }^{16}$ As Martín-Barbero points out: 
the indigenous world seems to be the only thing which remains for us of the "authentic," that secret place in which the purity of our cultural roots remains and is preserved. (459)

However, an open and reflexive note persists through the film. It is evident that the solitary act of this couple in 1980 (i.e. taking the documents and publishing them in the newspapers) is not enough for the recovery of national identity or complete national liberation. The ruling class knows that "this country does not have memory. After the scandal, everybody will forget the 'truth," as Carvallo cynically tells Figueiras. Cubagua does not resolve the situation for the audience. The end can be as bright, unknown and open as was the cave for Nila, the Native woman. In this way, the film questions the spectator, who has to be active in his/her next decision and action.

This film primarily addresses a Venezuelan audience, a "nation without memory," a nation whose "democratic" governments and ruling classes allowed successive invasions of foreign investors to the detriment of the cultural, political and economic interests of the nation. Venezuela is considered to be the wealthiest country in Latin America, but it is a country,

where only $57 \%$ of the population can have more than one meal daily. This situation motivated strong protests and civilian unrest from the poorest sectors in the country, and a recent failed "coup d'etat" from middle military officials, who intended to fight the corruption, the excessive bureaucracy, and the demagogy of the current democratic government. . . . Venezuela's Energy Minister said the coup attempt would not interrupt oil production or exporting, a daily total of 1.9 million barrels. ("Venezuela" A10)

It is interesting that in February 1992, the main concern of the Venezuelan Government after the coup d'etat (the first of two in the same year) was primarily to streng then their ties with the transnational companies, not to solve national social, economic and political problems. This reveals that the critiques made by historians, writers, journalists, and filmakers through the years are founded on factual evidence, and cannot be said to be "a fiction made up by subversives"; there are plenty of traces of the effects of transnational enterprise in the current rearrangement of the world capitalist system.

It is amazing to learn that at the same time that Carlos Azpurua's documentary, Amazonas, el negocio de este mundo, was attacking the foreign invasion behind the "national" project "The Conquest of the South," and that New's film Cubagua was denouncing through a fictional (hi)story the transnational interests behind the "Proyecto Progreso," the Venezuelan government was working arduously with 
transnational corporations to expand the oil and tourism industries. Much to the detriment of the national population and environment, this occurred on the very same site that was portrayed in Cubagua.

In September 1990, the American Embassy in Caracas informed its associates in the U.S. of the development of the Venezuelan Petroleum industry, including the "Cristobal Colon Liquefied Natural Gas Project," described in the embassy's report as a joint venture designed

to exploit the huge offshore gas reserves found to the north of the Paria Peninsula, in eastern Venezuela. The peninsula is where CHRISTOPHER COLUMBUS first landed in South America, and the project, Cristobal Colón, has been named after him. PDVSA's operating subsidiary, Lagoven, together with SHELL, EXXON, and MITSUBISHI, will produce, process, and transport the gas, as well as market it abroad in the form of liquefied natural gas. The $\$ 3$ billion project, approved by the [Venezuelan] Congress, will be the first since the 1975 nationalization of the hydrocarbons sector to include foreign equity. Majority equity of the project will be held by the foreign partners.

Moreover, Cubagua, the Venezuelan island of nine square miles that has experienced invasions since the early 1500 s, will be invaded again for "one of the Caribbean's biggest resorts if a consortium of Venezuelan and overseas developers gets its way" (Luxner 39). According to Luxner's report, the actual Cubagua, whose current population totals twenty-eight native fishermen and their families,

will be turned into a 8,000-room hotel resort. In addition, the project calls for the construction of two aquariums, a highway system, a shopping mall, a nautical club, two 18-hole golf courses, a sewage system and a water desalination plant. In the few acres remaining, developers hope to located a plastic, metal and glass recycling plant, not to mention a health spa, a marine investigations center and a small base for the Venezuelan Air-Force. Among the developers behind the Cubagua project are the [Venezuelan] Delfino Group, as well as investors from the United States, Japan, Germany, Holland, France, Italy and Malaysia. (Luxner 39)

Cubagua, five years after its release in 1987, has been exhibited in several Latin American and international film festivals as an example of current Venezuelan cinema. But, beyond its cinematic value, its political and historical critique is even more compelling in 1992 than at the time of its release. Almost five hundred years after the first Spanish settlement on its shores, the island of Cubagua is still attractive to former and new foreign investors: whether the object is 
pearls, oil, strategic minerals, or tourism, the (trans)historical pattern is repeated. Each time, the national ruling classes have allied with the "overseas developers" for their own benefit, even as the Native peoples (most recently the twenty-eight fishermen's families) continue to fight back for their right to self-determination and independence.

In this context, Cubagua is an excellent example of the New Latin American cinema's engagement with the historical search for national identity, and also its commitment to giving voice to the resistance and cultural struggles of subaltern groups. Additionally, Cubagua points out the active role of indigenous and mestiza women in the cultural and political struggle against different invaders, breaking the stereotype (repeated for centuries by official history) of indigenous and mestiza women as traitors who gave the native land to the foreigners. In Cubagua, Nila, the symbol of the "mestiza," not only leads the resistance but also denounces oppression; she awakens the people's conscience, and creates hope for a new and brighter future for the nation's complete liberation.

\section{Notes}

1 Translation my own. "El cine indigenista sería un cine que toma partido: es decir, conoce o cree conocer de antemano lo mas importante de una situación y se orienta hacia el testimonio, la denuncia o la propagandización de aquella. En consecuencia, ello se traduce en la priorización de ciertos temas entre muchos otros posibles, atendiendo la importancia movilizadora que ellos pueden tener en determinados espacios y circunstancias."

${ }^{2}$ List of documentaries by Venezuelan filmmakers cited by Coppens, who points out that his inventory is still incomplete (150 documentaries) because many filmmakers did not register their films with the National Office of Indigenous and Frontier Affairs (which has only nine of these 150 ) that was established by Decree 250 of 1951. Many of these documentaries were made by foreign filmmakers, anthropologists and organizations (from Germany, the US, Japan, and France among others) who without any obstacles entered indigenous areas, interrupted their private rituals and ceremonies, and left the tribes and the country without paying any taxes or returning the information to the community.

3 "Yo nunca me quise convertir en evangélico, ni en católico,porque siempre he querido mantener mi tradición". [I never wanted to be either evangelical or catholic, because I want to keep my tradition], qtd. in Gettino.

4 For other works on Venezuelan history, see also Brito, Picón, Malave, and Arreaza. 
5 "When I reached this Punta del Arenal, I found that the island of Trinidad formed with this land [which I called] Gracia. . . ."

${ }^{6}$ My own translation: "La historia escrita por razas dominadoras será siempre distinta a la interpretación que puedan darle los pueblos vencidos u oprimidos. . . L La Conquista no concluye en el siglo XVII. $\mathrm{Ni}$ la Colonia propiamente finaliza en la Independencia. Fluye todo esto en una permanente actualidad. Son tres etapas que se prolongan hasta nuestros dias. Se diría que todo nuestro pasado fuera presente."

${ }^{7}$ Fray Pedro de Aguado. Historia del Descubrimiento y de la Fundación de la Gobernación y Provincia de Venezuela. Caracas, 1582, cit. in Jiménez, also in P. Carrera.

${ }^{8}$ My own translation: "La hostilidad de los indígenas no era solo contra los rescatadores [de perlas y de esclavos indígenas] sino contra todo español, ademas nos permite evidenciar la capacidad de organización y unidad que tenían las diferentes comunidades, independientes entre si, cuando el caso lo requería."

9 “La Trepadora es mi primer libro optimista. . . La Trepadora es ansia de mejoramiento y por lo tanto implica confianza en el porvenir . . . [Asi], llena de alegría en Victoria, y de sereno gozo interior en Adelaida, la trepadora que brotó de la gleba y creció para ahogar cuanto se dejara aprisionar entre sus bejucos, termina adornando con un florido festón la aristocracia de la Casa Grande." Gallegos' letter to his friend F.Paz, qtd. in Gallegos, La Trepadora.

${ }^{10}$ My own translation of: "[Nila fue a Europa a Norteamérica]. . [alli] deslumbraba [a sus profesores] con sus perlas. . . sus relatos. / El blanco comenzaba a tejer en torno a ella su espesa red de artíficios. Al menos la suponía incauta, fácil; pero de pronto aparecía la hija de Rimarima y de las tierras que no desatan su secreto. / El hombre rara vez entiende esto. En la mujer se halla todo, la vida, la fuerza. El hombre se precipita a ella con un impulso ciego e ignora que el apenas es un instrumento."

${ }^{11}$ The film was co-produced by Cine-ULA (Mérida, Venezuela), ICAIC (Cuba), and GECU (Panama); edited by Justo Vega and Roberto Siso.

${ }^{12}$ Quintero, New, and Luis Nogueras wrote Cubagua's script.

${ }^{13}$ My own translation of "Todos los tiempos funcionan e interactúan en un mismo campo de simultaneidad en el que cada individuo representa un linaje transhistórico, ternamente presente. Tal vez la monoexpresividad de Leiziaga en el film se justifique por el hecho de que es el el viajero inmóvil del tiempo, o más bien, de que es en el donde se revela el tiempo transhistórico, que todo lo produce en su eterno retorno simultaneo, aún a él, Leiziaga, autómaton transhistorizado, y a todos 
los diferentes personajes, repetidos insidiosamente bajo atuendos variables, esclavizando Indios o sobornando periodistas."

14 As Simon Bolívar defined the Latin American people in his speech at the Congress of Angostura in 1819.

${ }^{15}$ On "La Malinche" and "malinchismo," see also Montes, Franco, and Cypess.

${ }^{16}$ It is interesting to point out that before Plato portrayed in his Republic the allegory of the cave as a way to search the light and get knowledge, the Caribe and Arawac tribes of the Northern coast of Venezuela used the cave as a sacred space where the "shamans" were initiated (Karina), or where a Native girl remained young forever (Wayuu). Cf.Perera.

\section{Works Cited}

American Embassy. Venezuelan Petroleum Industry: Development and Outlook. USDOC/International Trade Administration Market Research Reports: Sept 1990.

Anales para la historia de Venezuela. Vol II. Caracas: Biblioteca de la Academia Nacional de la Historia.

Anderson, Benedict. Imagined Communities. London: Verso, 1987.

Anzaldúa, Gloria. Borderlands/La Frontera:The New Mestiza. San Francisco: Aunt Lute, 1987.

Arreaza, Emperatriz. Violencia cultural en Venezuela. Maracaibo: Ediluz, 1982.

Brito, F. Historia económica y social de Venezuela. Tomo II.Caracas: Direc.Cultura.UCV, 1966.

Burton, Julianne. "The Hours of the Embers: on the current situation of Latin American Cinema." Film Quarterly XXX.1 (Fall 1976).

Calzadilla, J. "Entrevista a Michael New." Cubagua:un filme de Michael New. Ed. Cine-UlA. Merida: Ediciones del Dpto de Cine, 1987.

Carrera, German. Una nación llamada Venezuela. Caracas: Monte Avila, 1984.

Carrera, P. Cronistas e historiadores. Caracas: EBUC, 1982.

Chacón, A. Contra la dependencia. Caracas: Síntesis Dosmil, 1973.

Churchill, W. Literature, Cinema and the Colonization of American Indians. Monroe, Maine: Common Courage Press, 1992. 
Columbus, Christopher. The Four Voyages of Columbus. Ed. Coppens, $\mathrm{W}$. Inventario de películas realizadas en las zonas indigenas de Venezuela. Caracas: Instituto Autónomo Biblioteca Nacional, 1983.

Cronología del cine en Venezuela. Caracas: Cuadernos de la Cinemateca Nacional, 1989.

Cypess, Sandra. La Malinche in Mexican Literature: From History to Myth. Austin: U of Texas P, 1991.

Franco, Jean. Plotting Women: Gender and Representation in Mexico. New York: Columbia UP, 1989.

Gabriel, Teshome. "Third Cinema as Guardian of Popular Culture." Questions of Third Cinema. Eds. Jim Pines and Paul Willemen. London: BFI, 1989.

Gallegos, Romulo. La Trepadora. Caracas: Monte Avila, 1980.

Gettino, Otavio. "Cine Indigenista: entre la Inmovilidad y el Cambio." Plural, 2a.epoca. XV-IV.172 (Enero 1986).

Jiménez, Morella. Esclavitud indígena en Venezuela (siglo XVI). Caracas: Biblioteca de la Academia Nacional de la Historia, 1986.

Kearney, Richard. "The creativity of Language." Dialogue with Contemporary Continental Thinkers. Manchester: Manchester U Press, 1984.

Luxner, L. "Building on the Ruins." Américas 43.3 (1991): 39.

Malave, H. Formación histórica del antidesarrollo de Venezuela. Caracas: Ed. Rocinante,1975.

Martín-Barbero, Jesús. "Communication from Culture." Media, Culture and Society 10 (1988).

Mattelart, A. and Mattelart, M. International Image Markets. Comedia P.G., 1984 .

Montes, M. "Recovering the Lost Erotic Priestess of Caribbean Tradition." Woman as Myth and Metaphor in Columbia: U of Missouri Press, 1985.

Nuñez, Enrique Bernardo. Cubagua. Caracas: Monte Avila, 1988.

--. La Historia es pasión de actualidad. Discurso de inaguración. Academia Nacional de la Historia. June 1948. 
Oropeza, J. Para fijar un rostro: notas sobre la novelística venezolana actual. Caracas: Vadell Hermanos, 1984.

Perera, M. "Cuevas y cerros en la tradición oral y ceremonial de los amerindios de Venezuela" in Revista de Indias 51.193 (Sept-Dec1991).

Picón, M. De la conquista a la independencia. Mexico: FCE, 1969.

"Venezuela crushes army coup attempt." New York Times 5 Feb 1992: A10.

Wallerstein, Immanuel. The Modern World-System. London: Academic Press, 1974.

Wright, W. Café con leche: Race, Class, and National Image in Venezuela. Austin: U of Texas P, 1991. 